УДК 619:611.018.4:636.5

(C) 2017

\author{
Мазуркевич А. Й., доктор ветеринарних наук, \\ Малюк М. О., доктор ветеринарних наук, професор, \\ Харкевич Ю. О., кандидат ветеринарних наук,
} Савчук Т. Л., аспірант кафедри фізіології, патофізіології та імунології тварин Національний університет біоресурсів і природокористування України

\title{
ГІСТОЛОГІЧНІ ЗМІНИ У КІСТКОВОМУ МОЗКУ ЗА ЕКСПЕРИМЕНТАЛЬНОГО УШКОДЖЕННЯ КІСТКОВОЇ ТКАНИНИ
}

\section{Рецензент - доктор ветеринарних наук Б. В. Борисевич}

\begin{abstract}
Досліджено гістологічні зміни в кістковому мозку за експериментального ушкодження кісткової тканини. Аналіз гістологічних змін в кістковому мозку підтверджує закономірність $i$ характер розвитку репаративного остеогенезу. Встановлено, щзо механічна травма кістки призводить до вираженої реакиії в місці дефекту не тільки з боку кісткової тканини, а й з боку кісткового мозку. Також було встановлено, щзо з 14 доби починається інтенсивний остеогенез. Отримані дані можуть бути використані для розроблення методів стимуляції $i$ засобів попередження ускладнень під час відновлення кісткової тканини після травми.
\end{abstract}

Ключові слова: кістковий мозок, репаративний остеогенез, кісткова мозоль, процес остеорепараиії, гістологічний зріз, недеференційовані клітини, остеоцити.

Постановка проблеми. Травма кістки зазвичай спричиняє порушення структури не лише кісткової тканини, а й судин, нервів, кісткового мозку та м'яких тканин, що знаходяться всередині чи оточують пошкоджений орган [2].

Важливою проблемою ветеринарної хірургічної є вдосконалення методів зрощення переломів кісток у тварин. Успішне вирішення вимагає чіткого уявлення не тільки про техніку з'єднання та фіксацію відламків окремих кісток під час остеосинтезу, але й фундаментальних знань щодо динаміки гістологічних змін у тканинах, які відбуваються під час репаративної регенерації [5].

Аналіз останніх досліджень і публікацій, у яких започатковано розв'язання проблеми. За даними гістологічних досліджень різних авторів, від 5 до 15 відсотків травм проходять із порушенням термінів загоєння або закінчуються формуванням неповноцінного кісткового мозоля [4]. Інші автори під час гістологічних досліджень стверджують про різні етапи розвитку репаративного остеогенезу [6]. Гістологічна будова трубчастих кісток вивчалася в разі переломів [5], проте поза увагою дослідників залишилося ви- вчення мікроструктури кісткового мозку, яка $€$ важливою під час регенерації кісткової тканини.

Разом $з$ тим до сьогоднішнього дня ще не достатньо вивчено всі питання перебігу репаративного остеогенезу в умовах травми кістки, а гістологічні дослідження дадуть нам відповіді на зміни не тільки в кістковій тканині, а і в кістковому мозку за різних термінів регенерації.

Мета роботи - провести оцінку гістологічним змінам у кістковому мозку за різних термінів репаративної регенерації в кістковій тканині.

Завдання досліджень - вивчити зміни у кістковому мозку за різних термінів репаративної регенерації.

Матеріал і методи досліджень. Експеримент був проведений на 18 кролях-самках 3-місячного віку породи шиншила, масою тіла 2,5-3 кг, у відповідності до вимог «Європейської конвенції щодо захисту хребетних тварин, яких використовують в експериментальних та інших наукових цілях» (Страсбург, 1986), Закон України «Про захист тварин від жорстокого поводження» (15.12.2009. Відомості ВР, 2010, №9).

3 метою мінімізації рівня загального травматизму, ушкодження кісткової тканини моделювали в середній третині діафізу великогомілкових кісток, з медіальної поверхні шляхом нанесення дірчастого дефекту. Дефект наносили хірургічним свердлом діаметром 2,5 мм під загальним наркозом («Золетіл» 3 розрахунку 0,05 мг/кг ваги тварини). В місці розрізу проводили місцеву анестезію $0,5 \%$ розчином новокаїну. Оперативне поле розміром $2 Ч 2$ см вибривали та дворазово обробляли $5 \%$ розчином йоду (метод Філончикова). Всі процедури 3 операційного втручання проводили відповідно до вимог асептики та антисептики. Після формування дефекту операційну рану зашивали, тварин виводили з наркозу та утримували в стаціонарних умовах кафедри хірургії ім. академіка I. О. Поваженка.

Відбір проб тканин для гістологічних досліджень проводили на 3-тю, 7-му, 14-ту, 21-шу, 


\section{ВЕТЕРИНАРНА МЕДИЦИНА}

28-му і 42-гу добу експерименту. Для цього тварини піддавали евтаназії шляхом внутрішньовенного введення летальної дози натрію тіопенталу в дозі 90 мг/кг [3].

Від них відбирали зразки кісткової тканини з місцем дефекту, де проводили: фіксацію відібраних зразків, декальцинацію кісткової тканини, заливку блоків тканини целоїдином та виготовляли зрізи за допомогою санного мікротому [1].

Отримували гістологічні зрізи товщиною 7-9 мкм, які забарвлювали гематоксиліном-еозином [1]. При цьому, якість репаративних процесів у ділянці ушкодження оцінювали, враховуючи поверхневу структуру кістки, будову новоутвореної тканини, а також наявності та характеру розташування клітинних елементів в ділянці ушкодження.

Результати досліджень. Нами було проведено гістологічні дослідження кісткового мозку під час загоювання дефекту великогомілкової кістки в динаміці, починаючи з 3-ї і закінчуючи 42-ю добою після моделювання дефекту.

У результаті проведених досліджень встановлено, що на 3-тю добу кістковий мозок поблизу місця дефекту був інфільтрований великою кількістю зрілих еритроцитів (виразна гіперемія), серед яких виявлялися недиференційовані клітини, які на підставі зафарбовування гематоксиліном і еозином нам ідентифікувати не вдалося (рис. 1).

Частина таких клітин являли собою округлі клітини 3 округлим інтенсивно зафарбованим гематоксиліном ядром і невеликим обідком дещо базофільної цитоплазми, а частина - клітини бі-

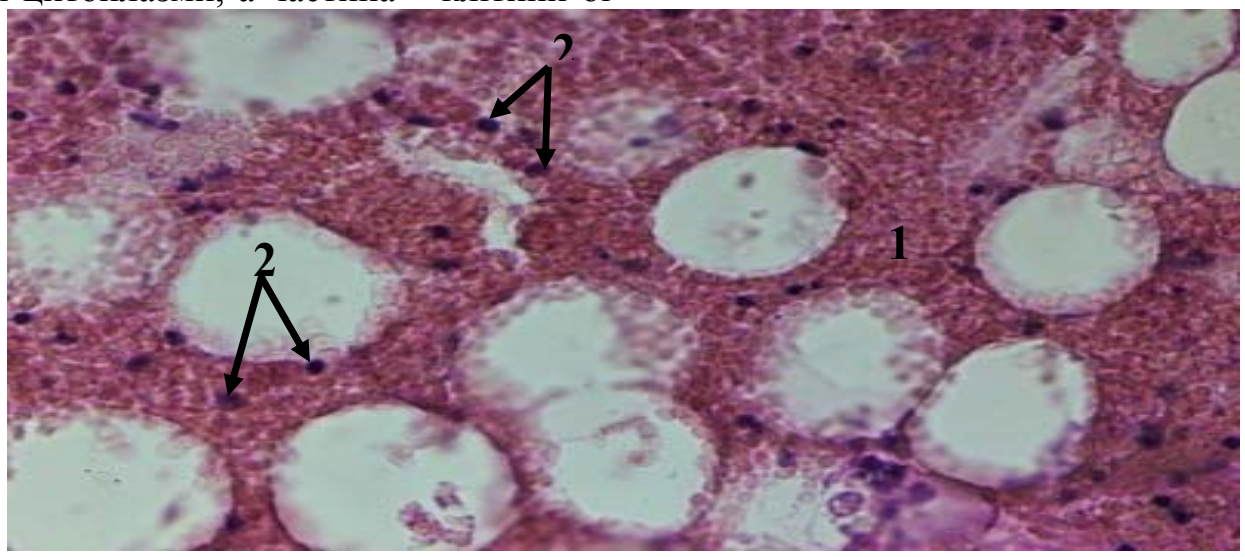

Рис. 1. Кістковий мозок поблизу місця дефекту на 3-тю добу після уикоджсеня кісткової тканини: 1 - інфільтрація еритроцитами; 2 - недиференційовані клітини. Гематоксилін Караці та еозин, $\mathbf{x} 400$. льших розмірів, які також мали округлі інтенсивно зафарбовані гематоксиліном ядра, але помітно більший об'єм цитоплазми, яка також характеризувалась дещо базофільними властивостями (рис. 1).

У центральній частині кісткового мозку як біля дефекту, так і віддалено від нього мікроскопічні зміни в цей термін спостереження нами зареєстровані не були. Проте в центрі кісткового мозку виявлялася надзвичайно виразно розширена вена, переповнена клітинами крові, яка проходила паралельно внутрішній поверхні кісткової тканини вздовж всієї кістки (рис. 2).

На 7-му добу у кістковому мозку поблизу місця дефекту реєструвалась виразна проліферація незрілих клітин та поодинокі мегакаріоцити (рис. 3).

Від місця дефекту до протилежної йому частини кісткової трубки через увесь кістковий мозок перпендикулярно до місця дефекту проходив тяж щільної волокнистої сполучної тканини.

У кістковому мозку віддалено від місця дефекту реєстрували розширення й переповнення кров'ю кровоносних капілярів (рис. 4).

На 14-ту добу в прилеглому до місця дефекту кістковому мозку нами було знайдено розростання волокнистої сполучної тканини та досить інтенсивний остеогенез з утворенням у цій ділянці кісткової тканини, що прилягала до поверхні новоутвореної в місці дефекту кістки (рис. 5).

На 21-шу добу мікроскопічні зміни в кістковому мозку у місці дефекту були аналогічні таким, що спостерігалися на 14-ту добу (рис. 6). 


\section{ВЕТЕРИНАРНА МЕДИЦИНА}

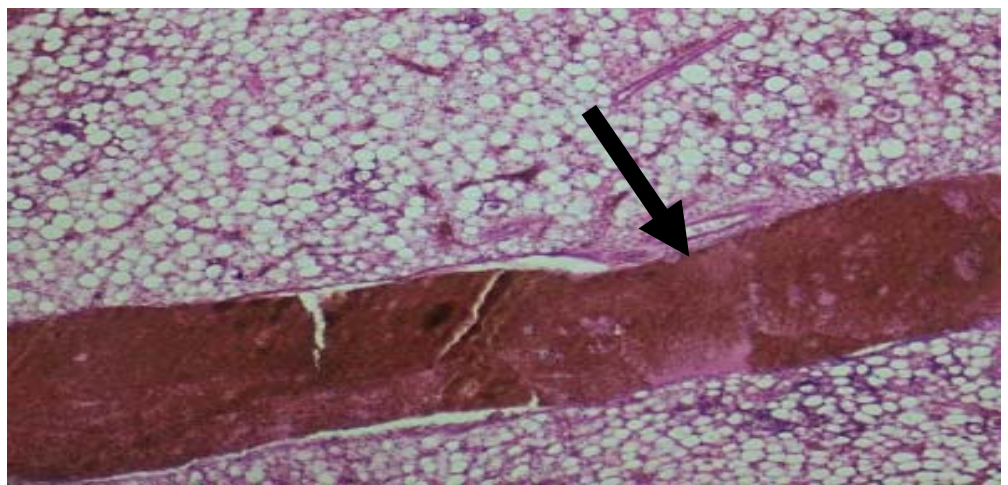

Рис. 2. Центральна частина кісткового мозку поблизу місця дефекту на 3-тю добу після ушкодження: розширена, переповнена кров'ю центральна вена (показано стрілкою). Гематоксилін Караці та еозин, $\mathbf{x} 50$.

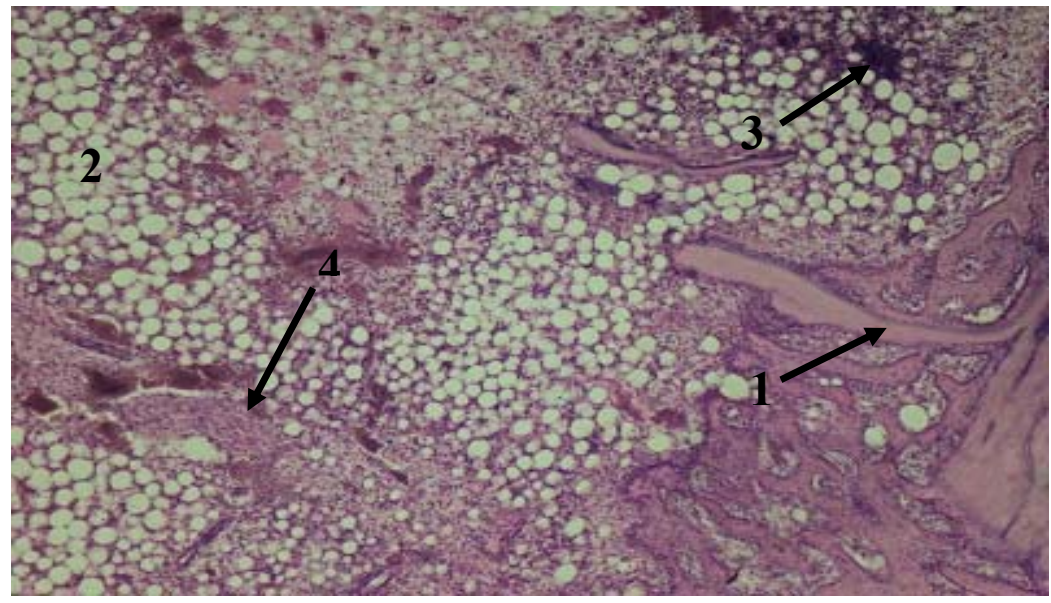

Рис. 3. Місце дефекту на 7-му добу після уикодження: 1 - остеогенез; 2 - кістковий мозок; 3 - проліферація незрілих клітин; 4 - тяэс щільної волокнистої сполучної тканини перпендикулярний до місця дефекту. Гематоксилін Караці та еозин, $x 50$.

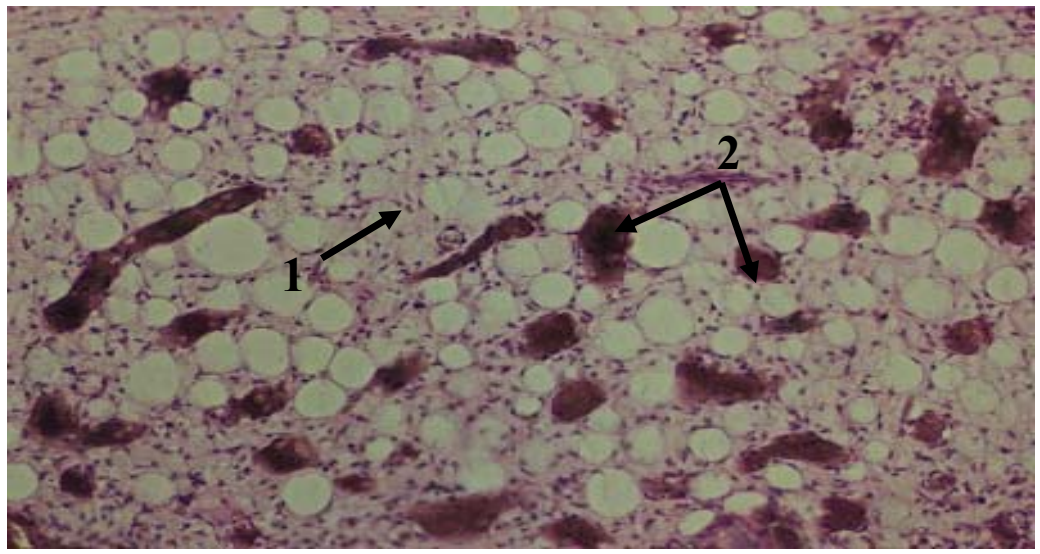

Рис. 4. Центральна частина кісткового мозку в місці дефекту на 7-му добу після ушкодження: 1 - незрілі клітини; 2 - розширені, переповнені кров'ю кровоносні капіляри. Гематоксилін Караці та еозин, х 100. 


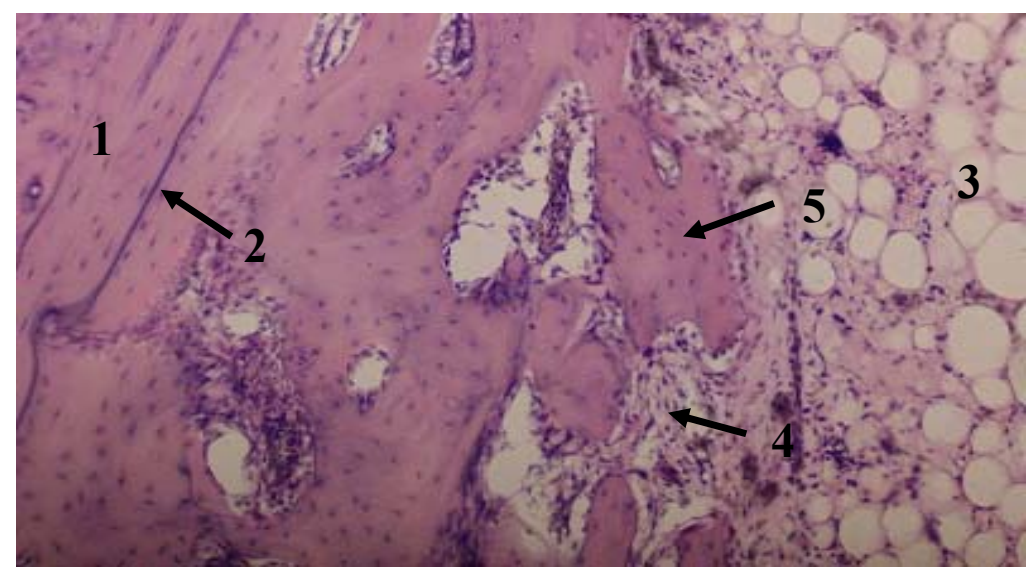

Рис. 5. Місце дефекту на 14-ту добу після ушкодження: 1 - новоутворена кісткова тканина; 2 - поверхня новоутвореної ділянки кістки; 3 - кістковий мозок; 4 - волокниста сполучна тканина; 5 -остеогенез у кістковому мозку. Гематоксилін Караці та еозин, х 100.

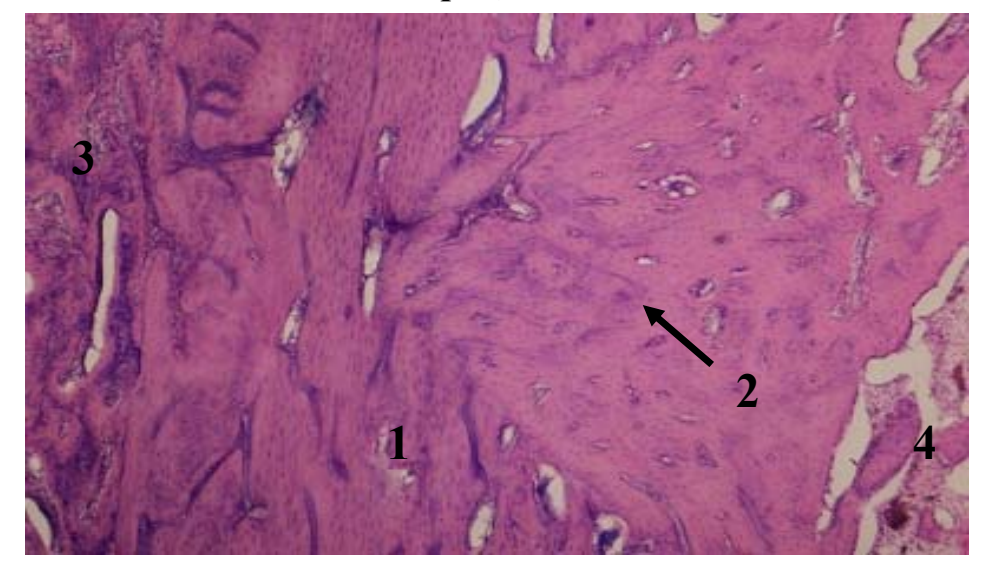

Рис. 6. Місце дефекту на 21-шу добу після ушкодження: 1 - новоутворена кісткова тканина; 2 - остеон; 3 - внутрішня частина кісткової мозолі; 4 - кістковий мозок. Гематоксилін Караці та еозин, $\boldsymbol{x} 50$.

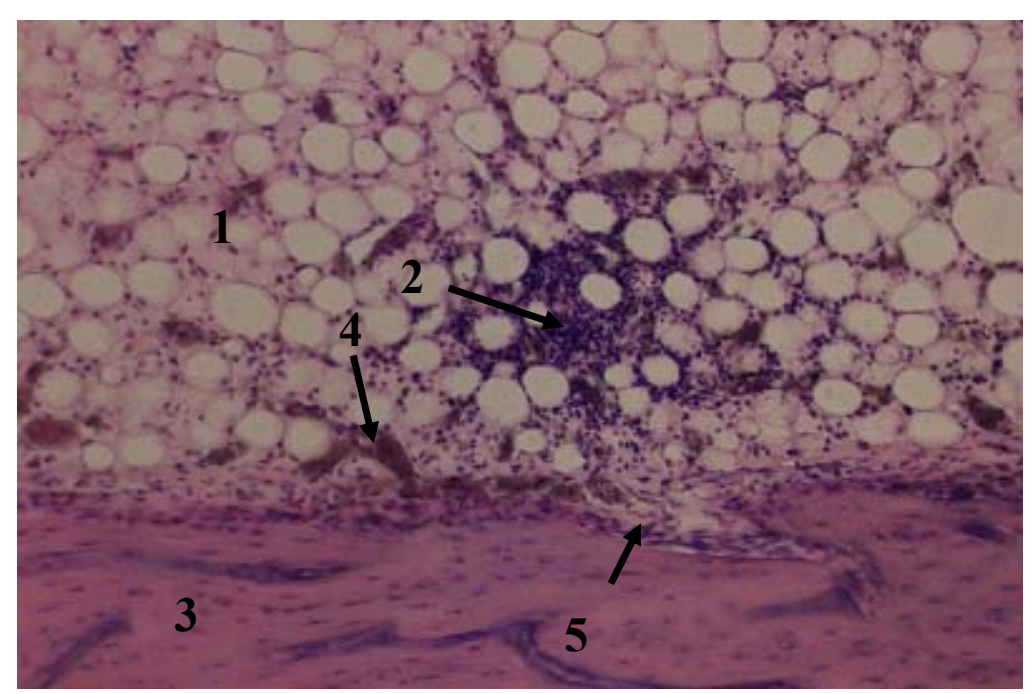

Рис. 7. Місце дефекту на 28-му добу після ушкодження: 1 - кістковий мозок; 2 - вогнище проліферації незрілих клітин; 3 -новоутворена кісткова тканина; 4 - крововиливи; 5 - остеобласти. Гематоксилін Караці та еозин, 100. 


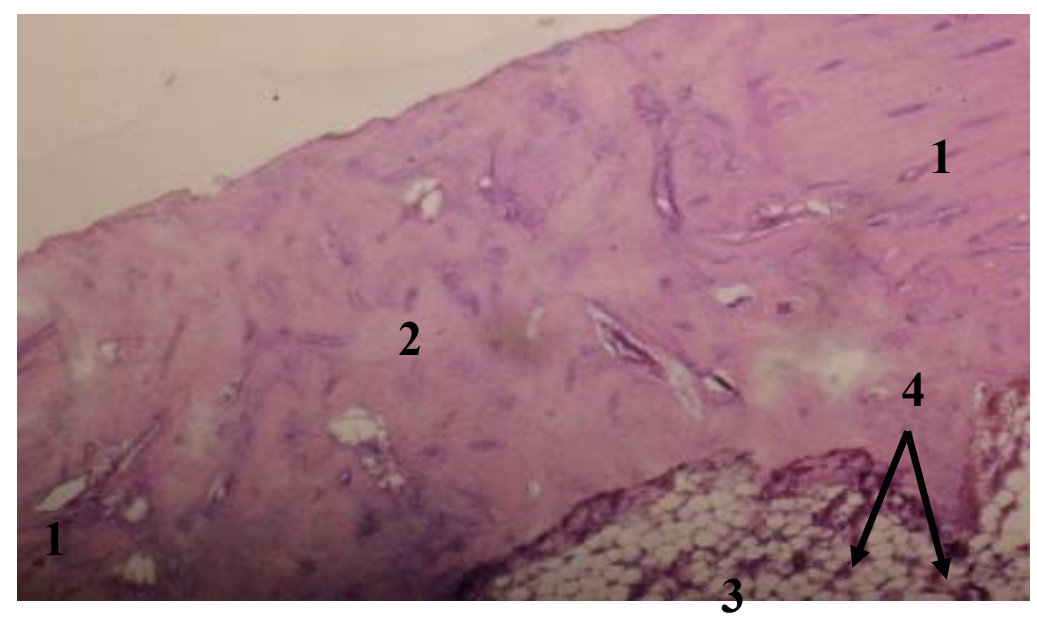

\section{Рис. 8. Місце дефекту на 42-гу добу після уикодження: 1 - інтактна кісткова тканина збоку від місця дефекту; 2 - новоутворена кісткова тканина; 3 - кістковий мозок; 4 - діперемія капілярів. Гематоксилін Караці та еозин, $x 50$.}

На 28-му добу з боку кісткового мозку поверхня новоутвореної кістки була ще нерівною. Тут все ще виявлявся виразний остеогенез. Поодинокі, невеликі, дуже рідко розташовані осередки остеогенезу також виявлялися в товщі кісткової тканини з боку кісткового мозку (рис. 7).

У кістковому мозку поблизу місця дефекту реєструвалися поодинокі невеликі вогнища проліферації незрілих клітин та крововиливи.

На 42-гу добу у кістковому мозку біля місця дефекту реєструвалися розширені й переповнені кров'ю кровоносні капіляри (рис. 8).

Будь-які інші мікроскопічні зміни кісткового мозку протягом експериментальних досліджень нами встановлені не були.

\section{Висновки:}

Встановлено, що механічне ушкодження кісткової тканини спричинює виражену реакцію 3

\section{БІБЛІОГРАФІЯ}

1. Горальський Л. П. Основи гістологічної техніки і морфофункціональні методи досліджень у нормі та при патології : навч. посіб. / Л. П. Горальський, В. Т. Хомич, О. І. Кононський. - Житомир : Полісся, 2005. - 228 с.

2. Дедух Н. В. Регенерация кости: основные тенденции развития проблемы / Н. В. Дедух, Е. А. Побел // Боль. Суставы. Позвоночник. 2013. - №1. - C. 89-90.

3. Джонс Л. М. Ветеринарна фармакологія i терапія / Л. М. Джонс ; пер. к. вет. н. А. С. Вишкера. - М., 1972. - T. 2. - С. 640-641.

4. Корж Н. А. Репаративная регенерация кос- боку кісткового мозку біля місця дефекту.

Було досліджено, що біля дефекту, так і віддалених від нього місць, мікроскопічні зміни в кістковому мозку спостерігалося тільки 3 3-ї по 7-му добу, де реєстрували розширення й переповнення кров'ю кровоносних капілярів та розширену вену.

Доведено, що в кістковому мозку біля місця дефекту на 3-тю добу з'являються недиференційовані клітини, з 7-ї по 28-му добу спостерігається виразна проліферація незрілих клітин.

Встановлено, що в кістковому мозку біля місця дефекту на 14-ту добу починається інтенсивний остеогенез, який зупинився на 42-гу добу.

Перспективи подальших досліджень. Планується проаналізувати зміни гістологічних досліджень у разі введення стовбурових клітин у травмовану кістку.

ти: современный взгляд на проблему. Стадии регенерации / Н. А. Корж, Н. В. Дедух // Ортопедия, травматология и протезирование. - 2006. - №1. - С. 76-84.

5. Петренко О.Ф. Гістологічні зміни при загоюванні переломів трубчастих кісток у великої рогатої худоби / О.Ф. Петренко, Б. В. Борисевич, В. В. Лісова // Науков. вісник Нац. аграр. ун-ту. - Вип. 42. - К., 2001. - С. 87-90.

6. Yoon S. T. Osteoinductive molecules in orthopaedics: basic science and preclinical studies / S. T. Yoon, S. D. Boden // Clin. Orthop. - 2002. Vol. 395. - P. 33-43. 